\title{
USE OF GEOGRAPHIC INFORMATION SYSTEM FOR DENGUE HEMORRHAGIC FEVER OUTBREAK MAPPING IN NORTH SULAWESI
}

\author{
Miranda Senduk, Angela Fitriani Clementine Kalesaran
}

Faculty of Public Health, Universitas Sam Ratulangi, Manado

\begin{abstract}
Background: The incidence of dengue hemorrhagic fever (DHF) has grown dramatically around the world in recent decades. Surveillance is essential to dengue management, because it identifies the number and distribution of cases, virus serotypes, and severity of disease in a population. Geographic information system (GIS) allows further investigation of surveillance data through spatial statistical analyses and visualization of patterns and relationships between disease and the environment. This study aimed to investigate the use of GIS for DHF fever outbreak mapping in North Sulawesi.

Subjects and Method: This was a descriptive study conducted in three regions in North Sulawesi province, from January to February 2019. All villages and subdistricts in the regions were selected for this study. The dependent variable was mapping of DHF outbreaks. The independent variable was use of the GIS. The data was obtained from North Sulawesi Health Office. The data was analyzed accordingly using Arcview software.

Results: The GIS showed that there were 13 villages in Manado, 7 villages in South Minahasa, and 7 villages in Southeast Minahasa with DHF cases. The highest case were in Paniki Bawah Village 28 cases, Rumoong Bawah Village 7 cases, and North Molompar 3 cases.

Conclusion: The GIS can be used to map the distribution of DHF cases, and to detect outbreaks. Future prevention and management programs related to DHF should be further implemented more consistently to reduce the incidence of DHF.
\end{abstract}

Keywords: geographic information system, DHF, outbreak.

Correspondence:

Angela Fitriani Clementine Kalesaran. Faculty of Public Health, Universitas Sam Ratulangi, Manado, North Sulawesi, 95115. Mobile: afckalesaran@unsrat.ac.id. Email: +62 81356270270 .

The $6^{\text {th }}$ International Conference on Public Health

Best Western Premier Hotel, Solo, Indonesia, October 23-24, 2019 | 47 https://doi.org/10.26911/the6thicph.01.24 